原著

\title{
開腹術後のイレウス発症と生活行動に関する研究
}

\author{
小泉 恵 ${ }^{* 1} \cdot$ 数 間 恵子*2 $・$ 川 村 佐和子*3
}

\section{Relationship between Postoperative Lifestyle and Onset of Ileus following Laparotomy}

\author{
Koizumi Megumi*1 ${ }^{*}$ Kazuma Keiko*2, Kawamura Sawako*3 \\ *1 Tokyo Medical and Dental University, Graduate School of \\ Medical Research Division of Doctor's Course \\ *2 Tokyo Medical and Dental University, School of Allied Health \\ Sciences Department of Nursing Science \\ ${ }^{*}$ Tokyo Metropolitan College of Health Sciences, Nursing
}

\begin{abstract}
The present study examines the factors related to the onset of ileus in patients who underwent laparotomy and then discharged. Thirty-two patients experienced a total of 57 episodes of ileus following laparotomy for gastric or colon cancer. In these patients, we investigated factors related to onset of ileus with respect to: 1) differences between the first and subsequent episodes, and 2) differences between the onset in patients who only experienced one episode and the first episode of recurrent patients.

The results were as follows: 1) the first onset correlated with a "lack of knowledge about ileus", "lack of knowledge about food", "events" and "sense of recovery". 2) "lack of knowledge about ileus" was related to the change from a sub-ileac condition to ileus. 3) "intake of foods that should be avoided" correlated with "lack of knowledge about food" and "over-eating". 4) When combined with "fatigue intake of foods that should be avoided" or "over-eating". "events" was most closely related to ileus. 5) Patients who underwent gastric surgery resumed their preoperative life-style once they felt a "sense of recovery", thus leading to the onset of ileus, and 6) When patients were educated about the ileus, recurrence was most strongly related to the surgically treated organ rather than postoperative lifestyle.

These findings suggest that recurrence of ileus can be prevented by educating patients about the appropriate behavior, including food preparation and activities that can affect their subileac condition, in a timely manner following laparotomy.
\end{abstract}

\section{要旨}

開腹術退院後のイレウス発症予防に資する目的で, 胃癌, 大腸癌による開腹術退院後の イレウス発症 32 例, 延べ57件を対象に，1）初回と 2 回目以降, 2) 1 回のみの例と, 再発 例の初回，それぞれについて発症関連要因を検討した。

\footnotetext{
$* 1$ 東京医科歯科大学大学院医学系研究科博士課程 $* 2$ 東京医科歯科大学医学部保健衛生学科看護学専攻

*3 東京都立保健科学大学看護学科
} 
その結果, 1. 初回発症には,「イレウスの知識不足」「食品の知識不足」「イベント」「回 復感」が影響していた．２．「イレウスの知識不足」は，サブイレウス状態から発症を招く 可能性があった。 3.「要注意食品の摂取」は「食品の知識不足」「過食」と関連があつた. 4.「イベント」は「疲労」「要注意食品の摂取」「過食」を伴い, 発症につながる可能性が 高いと考えられた. 5. 胃癌術後例では, 「回復感」を契機に術前の生活行動に近づき, 発症 に至つた可能性が考えられた. 6. 知識習得後の再発例の背景には, 切除臟器の相違の影響 が考えられた，以上から，看護支援として，サブイレウス時の対処法や要注意食品の食べ方 を含めた生活行動に関して, 適切な時期を考慮した継続指導の必要性が示唆された.

\section{I. 緒言}

開腹術退院後のイレウスは, 原疾患の治療後 に生じ, 術後の生活の質を低下させるという点 で，軽視できない問題である. 開腹術後のイレ ウス発症頻度は, 胃手術後で約 $1 \sim 35 \%$, 結腸 直腸手術後で約 $3 \sim 13 \%^{1 \sim 3)}$ といわれ，他の 後遺症の発生頻度と比較して必ずしも高くない. また, 癒着の発生機序 ${ }^{4)}$ からも, 医療従事者が イレウスを問題ととらえにくい，そのため, 開 腹術後早期のイレウス発症を予防する取り組み に比べ, 開腹術退院後のイレウス発症の予防は, イレウスを発症して初めて, きっかけとなった 要因を患者が独自に学習するに任せている現状 である.

開腹術後，一般的には食事指導が行われてい るが, それは, 術後の体力回復を優先し, 臟器 切除に伴う機能の欠落や摂食障害, 栄養障害に 焦点があてられ，必ずしもイレウス予防を意図 した内容ではない。 また，一旦，食行動上の注 意を理解しても，イレウス発症により入退院を 繰り返す事例の看護経験から，イレウス発症に は食行動の影響だけでなく，食行動を含む生活 行動全体に影響する要因の関連が考えられた。

そこで本研究では, 生活行動を中心とした開 腹術退院後のイレウス発症関連要因について調 ベ，イレウス発症予防の看護に資することを目 的とした.

\section{II. 研 究方法}

\section{1. 用語の定義}

開腹術退院後に，医師が腸閉塞と判断したも ののうち, 入院による保存療法, あるいは外科
療法のいずれかを要したものを「イレウス」, 入 院を要さない程度のものを「サブイレウス」と する。 また, 開腹術後入院中に発症した腸閉塞 は「早期イレウス」とする.

\section{2. 対象}

1993 年 1 月〜 1996 年 9 月に, 都内大学病院 とその関連病院外科において, 胃癌, 大腸癌に よる開腹術を受けて, 退院後にイレウスを発症 した例 (ただし, 腹膜播種例, 強力な放射線治 療・化学療法併用例, 胃癌・大腸癌の異時性再手 術例は除外) とした.

うち, 調査の承諾が得られ, イレウス発症直 前からイレウス治療までの経緯を詳しく想起可 能であった計 32 例(イレウス発症経験延べ57件) を対象とした。

\section{3. 調査期間}

1996年 $2 \sim 9$ 月

\section{4. 調査方法・内容}

質問紙を用いた半構成的面接，および入院病 歴・外来診療録の調査を行つた.

質問紙の作成は, 以下の手順で行った.

まず, 胃癌術後 3 例, 大腸癌術後 2 例に詳細 な面接を行い, 得られた資料と文献から，イレ ウスとの因果関係が推測される要因を抽出した. それらは, 生活行動とその修飾要因からなるイ レウス発症関連要因 (以下, 発症関連要因とい う) 10 項目 (表1-1) と, 生活習慣とその影響要因 8項目(表1-2)である.

これら各要因とイレウス発症との関係を研究 の枠組み(図1)とし，これに従つて質問紙を構 
表1-1 イレウス発症関連要因

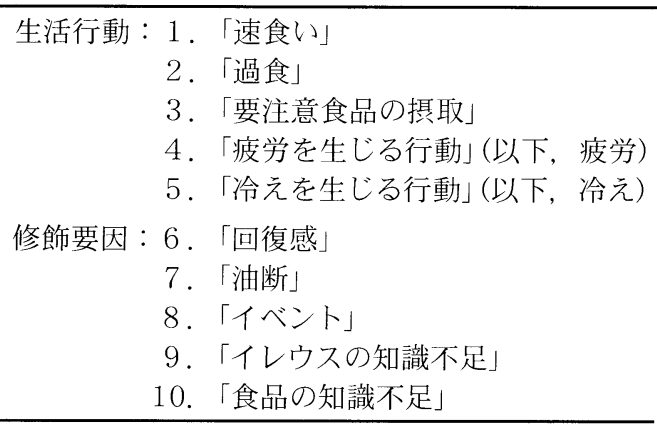

表 1-2 生活習慣と影響要因

$\begin{aligned} & \text { 生活習慣 }: 1 \text {.「食事」 } \\ & 2 . \text { 「排泄」 } \\ & 3 . \text { 運動・労働」 } \\ & \text { 4.「休息・睡眠」 } \\ & \text { 5.「イレウスの予防行動」 }\end{aligned}$

影響要因：6。「身体状況」

7.「健康に対する関心」

8.「対処行動」

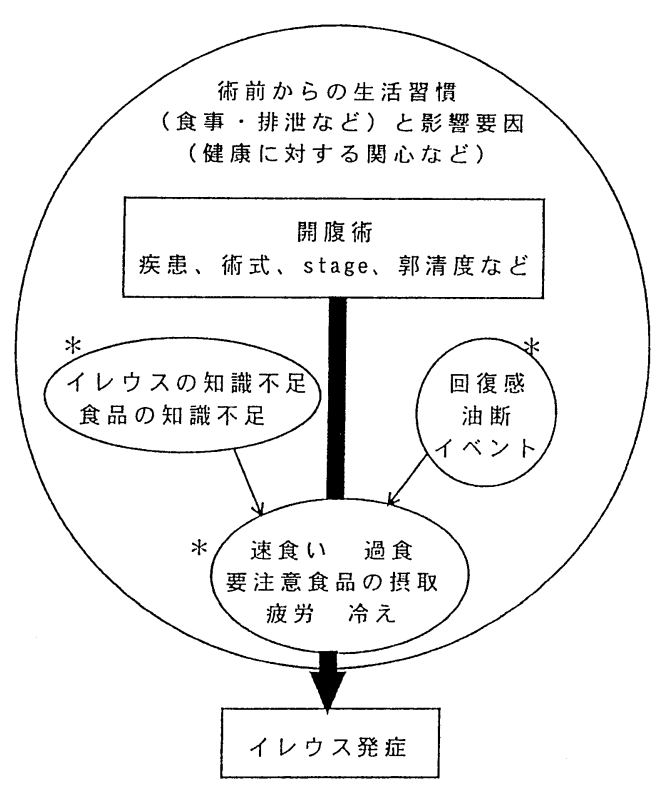

*：「イレウス発症関連要因」

図 1 研究の枠組み

成した. 各項目については, 開放的質問を行い, その有無や程度についての資料を得た。

なお, 対処行動とは, 人が問題状況に直面し たときにとる行動で, その調査には3つの尺度 (Confrontive因子, Emotive因子, Palliative
因子) で測定する Jalowic ら ${ }^{5)}$ のCoping Scale

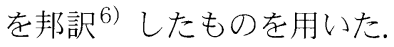

\section{5. 資料収集手順}

対象者が外来通院の場合は, 外来診察の前, あるいは後にプライバシーが確保できる場所で 面接し，入院中の場合は，病棟で同様に行った。 面接内容は，質問紙に詳細に記録すると同時に， 承諾を得て録音を行った。

また，対象者の診断，治療経過については入 院病歴，外来診療録の閲覧亡担当医からの聞き 取りにより情報を得た。

6. 分析方法

パソコン用統計学プログラム・パッケージ “HALBAU”を用いた量的解析と，イレウスの 発症経過に沿った事例の質的分析とを併用した.

なお，本研究では，「生活習慣とその影響要 因」をイレウス発症の背景と位置づけたため, イレウス発症に直接関連したと考えられる「イ レウス発症関連要因」10項目に焦点を当てて分 析を行つた.

\section{III. 結果}

\section{1. 対象の背景 (表2)}

対象は，男性23例 (72\%)，女性9例 (28\%) で，平均年齢と標準偏差は59.4土9.5才，原疾 患は胃癌 19 例 (59\%)，大腸癌 13 例 (41\%) で あった。術式, 組織学的進行度 (以下, stage と いう)，リンパ節郭清度(以下，郭清度という） は，表2のとおりである。

イレウス発症回数は，1〜 5 回で，1回18例 (56\%)，2回7例 (22\%)，3回5例 (16\%)，5 回2例 $(6 \%)$ であつた。

開腹術後, 初回イレウスまでの平均期間と標 準偏差は23.1 土28.3力月で，疾患別では，胃癌 術後の方が大腸癌術後より短く，イレウス発症 回数別でも，2回以上の方が 1 回のみより短かつ たが，いずれも統計的には有意ではなかった。

早期イレウス経験者は7例 (22\%) で，うち 6 例が大腸癌術後例，サブイレウス経験者は19例 (59\%)で，うち初回イレウス発症以前の経験者 は9例であった。 
表2 対象の背景 (例数 $(\%))$

\begin{tabular}{|c|c|c|c|c|c|c|c|c|c|c|}
\hline & $\begin{array}{c}\text { 全 体 } \\
32(100)\end{array}$ & $\begin{array}{l}\text { 男 性 } \\
23(72)\end{array}$ & $\begin{array}{l}\text { 女 性 } \\
9(28)\end{array}$ & & & & & & & \\
\hline 年齢 (才) & $\begin{array}{l}\text { 平均 } \pm \text { SD } \\
59.4 \pm 9.5\end{array}$ & $\begin{array}{c}\text { 平均 } \pm \mathrm{SD} \\
59.6 \pm 10.9\end{array}$ & $\begin{array}{l}\text { 平均 } \pm \mathrm{SD} \\
59.1 \pm 5.9\end{array}$ & & & & & & & \\
\hline 術式 $\cdot$ stage $\cdot$ 郭清度 & & & & \multicolumn{4}{|c|}{ stage } & \multicolumn{3}{|c|}{ 郭清度 } \\
\hline & & & & I & II & III & IV & $\mathrm{D} 1$ & $\mathrm{D} 2$ & D3 \\
\hline 胃癌 & $19(59)$ & & & & & & & & & \\
\hline 胃全摘＋R-Y & 14 & & & 3 & 3 & 3 & 3 & 4 & 8 & 2 \\
\hline 胃切 + B - I & 5 & & & 3 & 3 & 3 & 3 & 3 & 2 & 0 \\
\hline 大腸癌 & $13(41)$ & & & & & & & & & \\
\hline 横行結腸切除＋端々吻合 & 1 & & & 1 & 0 & 0 & 0 & 0 & 0 & 1 \\
\hline S 状結腸切除＋端々吻合 & 5 & & & 1 & 3 & 0 & 1 & 1 & 2 & 2 \\
\hline 直腸切除＋端々吻合 & 4 & & & 2 & 1 & 1 & 0 & 1 & 2 & 1 \\
\hline 直腸切断 + 人工肛門造設 & 2 & & & 1 & 1 & 0 & 0 & 0 & 1 & 1 \\
\hline 結腸全摘＋人工肛門造設 & 1 & & & 0 & 0 & 0 & 1 & 0 & 0 & 1 \\
\hline
\end{tabular}

なお, 疾患, 術式, stage, 郭清度, 開腹術 回数, イレウスの治療法, 早期イレウス発症の 有無, サブイレウス経験の有無と, イレウス発 症回数との間に関連はみられなかった.

さらに, 退院前に切除藏器に関連した食事・生 活指導を受けたのは15例 (47\%) で, 胃癌術後 19 例中 13 例 $(68 \%)$, 大腸癌術後 13 例中 2 例 (15\%)で，その差は有意であった $\left(\chi^{2}=8.7\right.$, $\mathrm{df}=1 ; \mathrm{p}=0.005)$.

イレウス予防に関連した食事・生活指導を受け たのは，開腹術退院前が6例 (19\%) で，イレウ ス発症後に受けた例と合わせると 22 例 (69\%) であった。

対処行動については, Coping Scaleの3因子 中, 得点可能最高点に対する点数比率が最も高 かったのは Confrontive因子で, 対象のCoping styleは全体として Confrontive傾向であ った.

\section{2. イレウスの発症に関する要因 (図2)}

延べ 57 件の半数以上で発症に関連する要因と してあげられたのは，「過食」36件 (63\%)が最 も多く，次いで「イベント」34件 $(60 \%)$ ，「疲 労」31件 (54\%), 「速食い」29件 (51\%)であ った。また，要因間では，「イベント」と「疲 労」との間に関連がみられた $\left(\chi^{2}=16.6, \mathrm{df}=1\right.$; $\mathrm{p}=0.00006$ ).

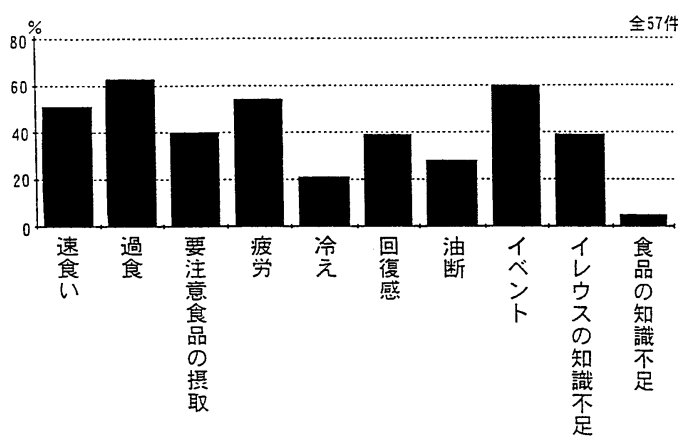

図2 イレウス発症における発症関連要因

3. イレウスの再発に関する要因

1）「初回」と「2回目以降」の検討

延べ57 件を初回イレウス(以下，「初回」とい う) 32 件と 2 回目以降イレウス (以下,「2回目以 降」という) 25 件とに分け, 発症関連要因に相 違があるかを検討した。

（1）両群間の発症関連要因の相違 (図3)

「回復感」と「イレウスの知識不足」は, と もに「初回」に多く, その差は有意であった $\left(\chi^{2}=\right.$ 17.6, $\mathrm{df}=1 ; \mathrm{p}=0.00003, \chi^{2}=13.3, \mathrm{df}=1$; $\mathrm{p}=0.0003)$.

「回復感」 20 件中, 胃癌術後例では, 体重増 加などを理由に「回復感」を感じ，それを契機 に，それまで指導を遵守していた例が，食べな いようにしていた食品を食べたり，運動量や仕 事量を増やして疲労を招いたりしていた。

「イレウスの知識不足」19件では，イレウス 


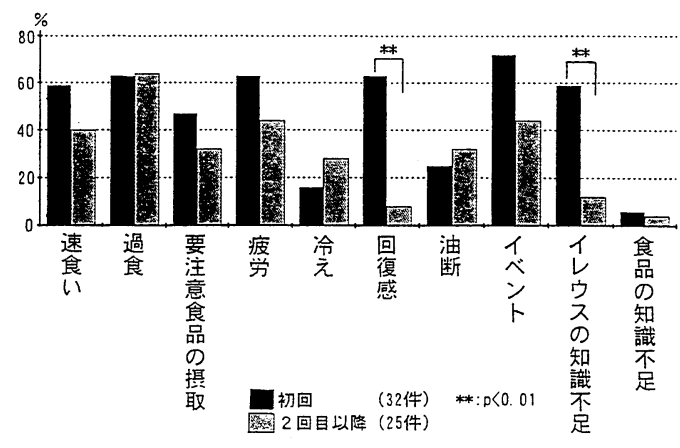

図3「初回」と「2回目以降」の発症関連要因の相違

の要因と指摘されている食行動の習慣が, 術後 も修正されなかった例 5 件, サブイレウスと診 断されたにも関わらず摂食した例 4 件があった. 後者 4 件中の 1 件は, 外来受診時に, サブイレウ ス状態での対処法を指導されずに帰宅し, 症状 が少し治まったために食事をしていた。 その他 にも，その状態がサブイレウスとは知らず食事 をした例があり, いずれもその直後に症状の増 悪を招き, 入院していた. 上記以外では, 開腹 術後の指導で食べることをただ奨励された例も 3 件あった。

（2）両群における発症関連要因間の関係の相違 両者ともに「イベント」と「疲労」との間で 関連がタられ（「初回」 $\chi^{2}=4.5, \mathrm{df}=1 ; \mathrm{p}=$ 0.049 ,「 2 回目以降」 $\chi^{2}=17.5, \mathrm{df}=1 ; \mathrm{p}=$ 0.0001), 「初回」ではさらに「イベント」と 「過食」との間にも関連がみられた $\left(\chi^{2}=4.5\right.$, $\mathrm{df}=1 ; \mathrm{p}=0.049$ ).

2)「1回のみ」群と「再発」群の検討

イレウスが 1 回のみの例 (以下, 「1回のみ」群 という) と再発例 (以下, 「再発」群という)の両 群で, 発症関連要因に相違があるかを検討した.

なお, 本研究は経過観測に打ち切りがあるた め, 以下a.b.の両基準を満たす例を「1回の み」例として「1回のみ」10例,「再発」14例 を選別した。

a ，初回イレウスまでにサブイレウス経験がな い.

b. 初回イレウスから調査までに 12.3 力月以上 経過している.
12.3 力月以上とした理由は, 再発例の初回か ら 2 回目イレウスまでの平均期間と標準偏差が $12.3 \pm 11.1$ 力月であったことによる.

なお, 両群間で疾患, 術式, stage, 郭清度, 早期イレウスの有無に相違はなかった.

また, イレウス再発の有無と, 対処行動のパ ターンの相違との関連があるかを調べるために, Coping Scaleの各因子得点を,「1回のみ」群 と「再発」群とで比較した．各因子とも，2 群 間の平均値に差はみられなかった。

（1）両群間の初回発症関連要因の相違 (図4)

両群間で相違があった要因は, 図4に示した とおり,「過食」「要注意食品の摂取」「イベン ト」「イレウスの知識不足」の4項目で，そのう ち「要注意食品の摂取」は統計的にも有意であ つた $\left(\chi^{2}=8.1, \mathrm{df}=1 ; \mathrm{p}=0.011\right)$.

また,「イベント」は「1回のみ」群全例にみ られ, 「要注意食品の摂取」重複例が8例, これ にさらに「過食」あるいは「食品の知識不足」 が加わった例は，それぞれ6例と1例であった。

\section{（2）「再発」群の2 回目以降の検討}

「再発」群の「イレウスの知識不足」11例中 8例は, 初回発症時にイレウス予防に関する指 導を受けたにも関わらず，再発していた。

その8例について, 2 回目以降のイレウス発症 の背景をみると, 胃癌術後 4 例では, 強い空腹 感のため「過食」や要注意食品の「速食い」な ど，食べ方のコントロールが難しい状況がみら れた. 大腸癌術後 4 例では, 前回のイレウスや

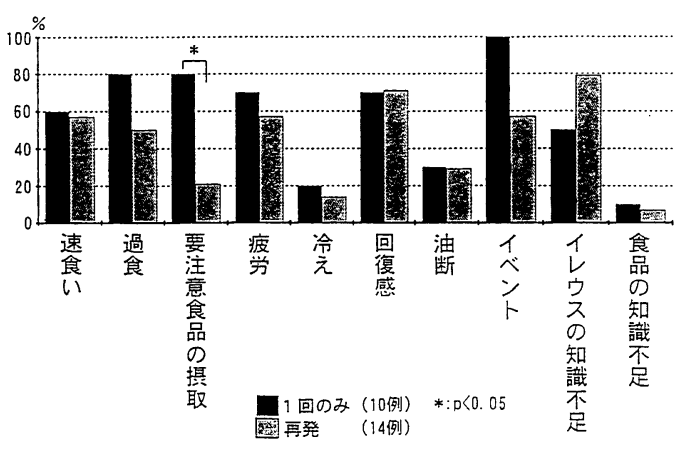

図4「1回のみ」群亡「再発」群の初回発症関連要 因の相違 


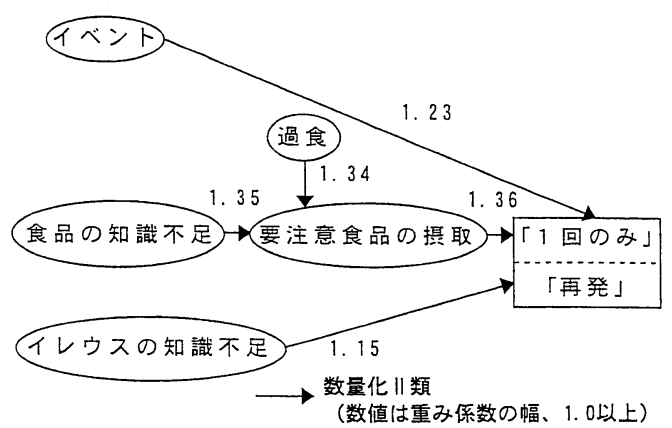

図5再発に対する初回発症関連要因間の関係

サブイレウスから順調に経過したための「油断」 から，要注意食品を食べていた，前回イレウス 後「油断」を感じるまでの経過月数は平均 11.3 カ月 $(3 \sim 12$ 力月) で, この時摂取した食品は, 麺類 (うどん，そば)，たけのこ，えのきだけ， ひじき，わかめ，とうもろこし，おはき，樽抜 きの柿であった.

（3）再発に対する発症関連要因間の関係 (図5)

各要因は，イレウス再発に単独で影響するだ けでなく, 要因相互に関連して影響している可 能性が考えられるため, 数量化 II 類を用い, 研 究の枠組みに沿って, イレウス再発に対する各 要因独自の影響の大きさを検討した.

イレウス再発に大きく影響していた要因(重み 係数の幅；1.0以上) は, 「要注意食品の摂取」 の 1.36 が最も大きく，ついで「イベント」の 1.23, 「イレウスの知識不足」の1.15であった. さらに，「要注意食品の摂取」には，「過食」の 1.34 , 「食品の知識不足」の 1.35 が影響してい た.

\section{IV. 考察}

以上の結果をふまえて，イレウスの発症予防 に関する看護支援として必要な指導内容と, そ の時期について考察する.

\section{1. 指導内容について}

1）「イレウスの知識不足」に対して：イレウス 予防に関する指導には，まず，イレウスの状態 や原因といった，イレウスの基本的な知識が必 要と考えられる。基本的な知識なしに，イレウ
ス発症の要因といわれる食行動や要注意食品を 列挙しても，例えば「イベント」のように日常 的でない状況では，その知識を応用できずイレ ウス発症につながる可能性が考えられる。 さら に，イレウス予防を食行動の注意に限定して考 えるのではなく，サブイレウス状態であるにも 関わらず摂食するといつた，誤った行動をとら ないために，サブイレウス症状や正しい対処法 について指導することも重要と考えられる.

2）「食品の知識不足」に対して：「食品の知識 不足」により実際に摂取していた食品は，いず れもイレウスの原因として指摘されているもの であり ${ }^{7,8)}$, 掑取には「過食」を伴っていた.

したがって，要注意食品名の指導の重要性に 加え, その食品のイレウスを発症しやすい性質 を，イレウスの基本的な知識と結びつけて指導 することが必要と考えられる.こうした指導は, 要注意食品の損取を禁止するのではなく, 調理 や食べ方の工夫次第で要注意食品も食べること ができるという, 開腹術後の食行動を積極的に 支援するものとして重要である.

3）「イベント」に対して：「イベント」の特徵 は,「疲労」を伴いやすいこと, さらに患者が食 ベることを強要されやすく, 出される食品を調 整したり，自分に適した食品を選択したりする ことが困難ということである. したがって「イ ベント」時は, 予防行動が崩されがちである.

そこで, 本人に対しては, 日常以上にイレウ ス発症の可能性が高くなること, 特に「要注意 食品の損取」や「過食」に注意するよう指導し， 周囲の人に対しても食べ方の個別性について理 解を得る必要がある。

4）イレウスの再発に対して：不足の知識を補つ てもなおイレウスを再発する背景として，胃癌 術後の場合では, 食事時間と低血糖様症状の出 現時間との関係から，「速食い」「過食」の裏に 後発性低血糖が存在する可能性が考えられる ${ }^{9)}$.

したがって, 現在, 退院時に行っている臓器 切除後の食事・生活指導に加え, 退院後の顕在 性・潜在性後発性低血糖を把握し, 低血糖を生 
じないような食行動を指導することも，イレウ ス予防につながると考えられる。

\section{2. 指導時期について}

切除臟器の種類によって発症関連要因に相違 があつたことから，イレウス予防の指導につい ても，それぞれに適切な時期を考える必要があ る.

\section{1）「回復感」に対して}

胃癌術後退院時の食事指導は, 少量分割摂取 などイレウス予防にも共通する内容であるため, 指導を遵守している間はイレウス発症の要因と なる食行動を起こす可能性は低いと考えられる. しかし, 胃癌術後の場合, 「回復感」をきっかけ に生活行動が術前の状態に近くなり, イレウス 発症に至った可能性が考えられることから,「回 復感」を感じる時期にも, イレウス予防の指導 を行う必要性が考えられる。

\section{2)「油断」に対して}

大腸癌術後では, 退院時の食事・生活指導が 実施されないことが多く, 加えて食べることを ただ奨励される人もいる. 胃癌術後に比べ, 術 後の体重減少や食事に関する困難も軽度である ことの「油断」から，イレウスの要因となる食 行動をとりやすいと考えられる. また，イレウ スやサブイレウスの経験後, 本研究結果では約 1 年間，再発せずに経過しており，このことも 「油断」を招きやすく, イレウス発症に至る可能 性が考えられる.

したがつて，まず退院時の大腸切除に関連し た食事・生活指導を実施し, 加えて術後やイレウ ス・サブイレウス発症経過後の「油断」を生じや すい時期に，生活行動を見直す働きかけが必要 と考られる.

\section{3）継続看護指導の必要性について}

患者の関心が, 例えば術後の痛みや体力回復 など，イレウス以外にある場合，患者はその時 点ではイレウスを自分の問題として受け取りに くい. 患者の関心が学習効果を左右すること ${ }^{10)}$ から, イレウスやサブイレウスの経験時は, 再
発防止のための指導の好機と考えられる. さら に, 医療機関内での指導に加え, 保健活動の一 端として，健康を回復し，社会的な活動に関心 が向けられる頃に, 潜在するイレウス発症の予 防について言及することも有用であろう。

\section{V. 結語}

開腹術退院後イレウスの発症予防の看護に資 する目的で, 胃癌, 大腸癌による開腹術退院後 にイレウスを発症した 32 例, 延べ57件を対象 に，1）初回イレウスと2回目以降イレウス，2） 1 回のみの例と再発例のそれぞれについて, 発症 関連要因を検討し，以下の知見を得た.

1. 初回イレウスの発症には「イレウスの知識 不足」「食品の知識不足」「イベント」「回復 感」が影響していた。

2.「イレウスの知識不足」は, サブイレウス状 態からイレウスの発症を招くことがあった.

3.「要注意食品の摂取」は, 「食品の知識不足」 「過食」と関連があった。

4.「イベント」はその特徵から,「疲労」や 「要注意食品の摂取」「過食」を伴っていた.

5. 胃癌術後例では，「回復感」をきっかけに術 前の生活行動に近づいて，イレウス発症に至 つた可能性が考えられた。

6. 再発は, 切除臟器によって背景が異なる可 能性が示唆され, 胃癌術後では後発性低血糖, 大腸癌術後では「油断」による影響の可能性 が考えられ，イレウス再発につながる生活行 動を生じたと推察された。

7. 開腹術退院後のイレウス発症を予防する看 護支援として，イレウスの症状や要注意食品 の食べ方などに関して, 適切な時期を考慮し た継続看護指導の必要性が示唆された.

稿を終えるにあたり，面接に快く応じて頂き ました患者の皆様と，調査にご協力いただきま した九段坂病院 山浦伊乷吉病院長, 河野佳代 子看護部長, 杉原国扶外科医長, 本学医学部第 一外科学講座 遠藤光夫前教授, 竹下公矢助教 授, 第二外科学講座 仁瓶善郎助教授, 佐々木 研究所付属杏雲堂病院 岩間毅夫外科部長はじ め医師, 看護婦の皆様に深く感謝申し上げます。 
なお, 本研究の要旨は第 17 回日本看護科学学 会学術集会において発表した。

\section{引用文献}

1) 松村長生, 松崎孝世, 西島早見, 他 : 癒着 性イレウスの統計的観察 本邦 40 外科施設 における7641例のイレウス統計より，日 臨外医会誌, 32, 53-62, 1971.

2 ) 森山雄吉, 恩田昌彦, 吉葉昌彦, 他: 臨床 統計よりみたわが国のイレウス，外科, 49 (12), 1389-1398, 1987.

3 ）沢田寿仁, 早川健, 堤謙二, 他：大腸癌 術後合併症としての早期イレウスについて, 日本大腸肛門病会誌, 49, 347-354, 1996.

4) 溝手博義, 掛川輝夫, 香月直樹, 他: 術後 イレウスの予防と対策, 臨床消化器内科, 4 (7), 1171-1178, 1989.

5 ) Jalowiec. A. \& Powers. M.J. : Stress and Coping in Hypertensive and Emergency Patients, Nursing Research, 30 (1), 1014, 1981.
6 ）佐藤正美, 数間恵子, 石黒義彦：直腸癌肛 門括約筋温存手術後患者の排便障害とセル フケア行動に関する研究 その 2 . セルフケ ア行動と排便障害影響要因, 日本ストーマ 学会誌, 12 (1), 39-50, 1996.

7 ）炭山嘉伸, 鈴木 茂：繰り返す亜イレウス一 この症例の診断と治療の方針, 外科, 49 (12), 1383-1388, 1987.

8 ）蜂須賀喜多男, 磯谷正敏：イレウス治療 (第1版), 83-86, 医学書院, 1991.

9 ）数間恵子, 原 雅子, 小林順子, 他：胃切 除後の「食べ方」要指導患者発見における 肝超音波所見の有用性に関する検討，第 9 回胃術後障害研究会プログラム・抄録集, 40-41, 1996.

10) Redman, B.K. : Assessment of motivation to learn and the need for patient education: The Process of Patient Education (7th ed), p. 34, C.V. Mosby, St Louis, 1993. 